que Greenwich pourrait dès maintenant fournir d'utiles renseignements, car la reproduction photographique de ses clichés de la carte l'a conduit, précisément, à exécuter les agrandissements de ces clichés en positifs sur verre. La Commission estime qu'il serait très désirable que l'Observatoire de Greenwich portât son attention sur cette question.

M. Jules Baillaud, qui a beaucoup insisté pour qu'on s'en tienne aux reproductions par l'héliogravure, seules capables d'assurer pendant des siècles la conservation de l'image du ciel à notre époque, revient sur un vœu adopté sur sa proposition au Congrès de 1932 ; de nouveau, il recommande que les Observatoires engagés dans l'entreprise n'abandonnent pas la prise des clichés de la série de la carte et s'efforcent de les reproduire par l'héliogravure, tout au moins dans la Voie lactée.

M. le Président observe que cette recommandation n'est pas en opposition avec la résolution précédente et qu'il ne peut avoir qu'avantage à s'y conformer dans la mesure du possible.

M. le Président signale des suggestions et communications qui lui ont été adressées par MM. Bellamy, Bemporad, Bhaskaran, Lacroute, Paloque, Perrine, et dont la plupart sont mentionnées dans son Rapport. L'heure avancée ne permet pas d'en aborder l'examen. Certaines d'entre elles, d'ailleurs, celles qui concernent, par exemple, les mouvements propres, les courants stellaires, les variations d'éclat, les étoiles doubles, etc.... sortent du cadre des attributions de la Commission, qui sont plus spécialement d'exécuter le Catalogue et la Carte photographiques. Sir Frank Dyson est aussi d'avis qu'il convient avant tout de terminer au plus tôt le travail du Catalogue et de la Carte.

\title{
COMMISSION 24. (PARALLAX AND PROPER MOTIONS.)
}

\author{
President: Prof. S. A. Mitchell. \\ Secretary: Dr W. M. SMart.
}

The Commission held two sessions. At the first session there was an interesting discussion in which the majority of the eighteen members of the Commission present participated.

The second session was given over to stellar parallaxes. Dr Adams described the methods followed at Mt Wilson in deriving the spectroscopic parallaxes of 4179 stars and Dr Schlesinger explained the methods for deriving the values given in the Second Yale Catalogue. Parallax programmes were discussed by various observers.

The Commission adopted the supplementary report on proper motions in the southern sky which follows:

\section{SUPPLEMENTARY REPORT, W. J. LUYTEN}

In the systematic survey of the southern hemisphere for faint stars with large proper motion the more important half of the work, viz. the part of the sky south of declination $-30^{\circ}$, has now virtually been completed. In this region, comprising 577 pairs of plates, a total of 556 , covering $97.5 \%$ of the area (due to overlap), have now been examined. A total number of nearly 70,000 moving objects have been found. While definite conclusions cannot be reached until all these motions have 
been measured and discussed, a few preliminary statements and indications may be of value.

(I) Foremost among these is one of disappointment in that no faint stars with very large motions have been found; not a single new motion exceeding 3 " annually, only 3 new stars with motions between $2^{\prime \prime}$ and $3^{\prime \prime}$ per annum, and no stars of the I 7 th magnitude or fainter with a motion as large as $I^{\prime \prime}$ annually.

In the supposedly much better known northern hemisphere Ross found, among some 800 new motions, one star with a motion as large as $5^{\prime \prime}$ and one other of more than $3^{\prime \prime} \cdot 5$ while recently a third, with a motion of $3^{\prime \prime} \cdot 7$ annually, was found at Minnesota, also in the northern hemisphere. While it is possible that the southern hemisphere is unusually poor in large proper motion stars, the present result does tend to indicate that stars of extremely low luminosity are not as abundant in space as has been claimed by recent investigators.

2. There appear to be some indications of a non-uniform distribution of proper motion stars over the sky, even after allowance is made for proximity to the apices of the various drifts.

3. A preliminary discussion of the favoured directions of motion-star streaming -is in progress, and promises to yield the usual results.

4. While more than Iooo double stars-wide pairs with common proper motion - have been found, not a single bona-fide triple and certainly no conspicuous moving clusters have been observed.

5. No faint distant companions to bright stars of large proper motion have been found, even though a special lookout was kept for such stars.

6. Some I200 new variable stars have been found, mainly belonging to the long-period class. Not a single certain variable with proper motion has been found, and only two cases where either the variability or the proper motion is only suspected, which result will have some bearing on the frequency of eclipsing binaries and W Ursae Majoris stars among dwarfs of low luminosity.

7. No proper motions of the Nova Pictoris type have been found, i.e. no stars apparently running away in opposite directions from the scene of an explosion. While it would be too much to say that such objects had been expected, we must not overlook the fact that, e.g., the B and C components of Nova Pictoris itself will probably be a matter of $3^{\prime}$ apart in rooo years, and by that time nothing except a record of their history would indicate a former association.

Dr Nechvile reports that the region with centre at R.A. $6^{\mathrm{h}} 30^{\mathrm{m}}$, Decl. $+24^{\circ}$ has been examined in collaboration with $M$. Bosler of the Marseille Observatory.

\title{
COMMISSION 25. (STELLAR PHOTOMETRY.)
}

\author{
Acting President: Prof. Ő. Bergstrand. \\ Secretary: Prof. B. Lindblad.
}

The acting chairman read a letter from the President of the Commission, $\mathrm{Mr}$ F. H. Seares, calling the attention of the Commission to certain points of importance which might be taken up for discussion. In the course of this discussion $\mathrm{Dr} H$. Shapley invited cooperation with the Harvard Observatory on the work of unification of the magnitude systems in the northern and southern sky.

After a discussion on the problems of standardizing colour filters and photographic plates used in stellar photometry the recommendation suggested by Dr Shapley 